\title{
ANALISIS KESALAHAN DAN SCAFFOLDING DALAM PENYELESAIAN PERSAMAAN DIFERENSIAL
}

\author{
Yunis Sulistyorini \\ IKIP Budi Utomo Malang \\ yunis.sulistyorini@gmail.com
}

\begin{abstract}
ABSTRAK
Tujuan dari penelitian ini adalah mendeskripsikan hasil analisis kesalahan dan scaffolding yang diterapkan dalam memperbaiki kesalahan matematika mahasiswa ketika menyelesaikan persamaan diferensial. Hasil penelitian diharapkan mampu memberikan gambaran bagaimana scafolding dapat diterapkan di kelas untuk membantu mahasiswa lebih mandiri dan terlibat aktif dalam pembelajaran. Jenis penelitian merupakan penelitian kualitatif deskriptif. Subyek penelitian adalah mahasiswa program studi Pendidikan Matematika IKIP Budi Utomo Malang yang menempuh matakuliah Persamaan Diferensial. Hasil analisis kesalahan menunjukkan bahwa kesalahan yang muncul dalam menyelesaikan persamaan diferensial adalah kesalahan konseptual, prosedural dan faktual. Secara umum, penyebab kesalahan adalah karena mahasiswa tidak mengoptimalkan pengetahuan awal yang sudah dimiliki terkait konsep turunan dan integral dan mahasiswa belum sepenuhnya memahami konsep dan prosedur dalam penyelesaian persamaan diferensial. Selain itu, mahasiswa juga sering menyelesaikan persamaan diferensial dengan hanya melihat dan meniru contoh yang sudah diberikan. Perbaikan kesalahan dilakukan melalui penerapan scaffolding yang merupakan variasi dari pemberian petunjuk, handout dan penjelasan pada mahasiswa. Variasi penerapan scaffolding juga didampingi dengan pemberian umpan balik dan motivasi terhadap mahasiswa. Variasi penerapan scaffolding ditujukan agar mengoptimalkan kemampuan mahasiswa dalam menyelesaikan persamaan diferensial. Mahasiswa juga lebih mandiri dan terlibat aktif dalam pembelajaran. Jadi, selain mampu memperbaiki kesalahannya mahasiswa juga memperoleh pemahaman yang lebih mendalam terkait penyelesaian persamaan diferensial sekaligus meningkatkan sikap dan performanya dalam pembelajaran.
\end{abstract}

Kata Kunci : Analisis Kesalahan, Scaffolding, Persamaan Diferensial.

\section{PENDAHULUAN}

Persamaan Diferensial merupakan salah satu matakuliah wajib bagi mahasiswa Pendidikan Matematika IKIP Budi Utomo Malang. Matakuliah Persamaan Diferensial meliputi penyelesaian persamaan diferensial biasa (PDB) dan persamaan diferensial parsial (PDP). Penelitian hanya dibatasi pada penyelesaian persamaan diferensial biasa. Matakuliah ini berhubungan dengan turunan dan integral dalam matakuliah kalkulus differensial dan kalkulus integral. Jika mahasiswa tidak sepenuhnya memahami konsep turunan dan integral maka kemungkinan besar mahasiswa akan kesulitan dalam menyelesaikan persamaan diferensial. Hal ini sesuai pernyataan dari Pazzani (1991) yang menyatakan bahwa pengetahuan awal akan berpengaruh terhadap kemudahan peserta didik 
dalam memahami konsep selanjutnya. Jadi, mahasiswa yang sudah memahami dengan baik konsep turunan dan integral akan lebih mudah memahami dan menyelesaikan persamaan diferensial. Sebaliknya, mahasiswa yang belum sepenuhnya memahami konsep turunan dan integral akan lebih besar kemungkinannya untuk melakukan kesalahan dalam menyelesaikan persamaan diferensial.

Kesalahan merupakan salah satu hal yang tidak dapat dipisahkan dalam pembelajaran matematika. Kesalahan merupakan dasar untuk mengkonstruksi sebuah konsep (Ingram, 2013) dan kesalahan juga dapat digunakan untuk mendukung pemahaman yang lebih mendalam terhadap matematika bagi peserta didik (Bray dan Santagata, 2013). Guru sebaiknya mau dan mampu menangani kesalahan peserta didik. Guru memegang peranan penting dalam menangani kesalahan peserta didik. Salah satunya dengan menciptakan lingkungan belajar yang toleran terhadap kesalahan. Kelas yang toleran terhadap kesalahan mampu memberikan dampak yang positif pada kemampuan afektif peserta didik (Rach, dkk, 2013). Peserta didik yang belajar di lingkungan yang toleran terhadap kesalahan tidak akan lagi takut jika melakukan kesalahan. Selain itu, guru juga sebaiknya memahami penyebab munculnya kesalahan, mencari cara dan berusaha memperbaiki kesalahan tersebut (Legutko, 2008; Schnepper dan McCoy, 2013; White, 2005). Penyebab kesalahan yang sistematis terkait dengan pengetahuan peserta didik yaitu pengetahuan prosedural, konseptual dan hubungan antara keduanya (Muzangwa dan Chifamba, 2012). Salah satu cara yang dapat dilakukan guru untuk memahami penyebab munculnya kesalahan dan menanganinya adalah melalui analisis kesalahan.

Analisis kesalahan merupakan salah satu metode yang dapat ditempuh untuk mengidentifikasi kesalahpahaman peserta didik dalam mempelajari konsep matematika (Ketterlin-Geller dan Yovanoff, 2009). Kesalahan yang diperhatikan dalam penelitian ini dibagi menjadi tiga jenis yaitu kesalahan konseptual, prosedural dan faktual. Kesalahan konseptual dalam penelitian ini terkait dengan konsep dan prosedur dalam menurunkan, mengintegralkan dan menyelesaikan persamaan diferensial variabel terpisah, reduksi variabel terpisah, homogen dan linier tak homogen. Kesalahan prosedural terkait dengan ketidakmampuan peserta didik untuk melakukan manipulasi atau algoritma meskipun memahami konsep yang dalam menyelesaiakan persamaan diferensial. Kesalahan faktual terkait kesalahan perhitungan dalam menyelesaikan persamaan diferensial. Ketiga kesalahan dalam penelitian ini dijadikan dasar bagi peneliti untuk menentukan langkah perbaikan kesalahan dalam menyelesaikan persamaan diferensial. 
Langkah yang diambil peneliti untuk memperbaiki kesalahan mahasiswa dalam menyelesaikan persamaan diferensial adalah melalui scaffolding. Konsep scaffolding digunakan untuk mendefinisikan dan menjelaskan peran dari orang yang lebih dewasa atau orang lain dalam mendukung perkembangan dan pembelajaran bagi peserta didik (Bikmaz, dkk, 2010). Lebih lanjut, Bikmaz, dkk (2010) menjelaskan bahwa scaffolding merupakan dukungan yang diberikan oleh orang lain secara terkontrol untuk membantu peserta didik ketika menghadapi kesulitan dalam memecahkan masalah dengan kemampuannya sendiri. Scaffolding dalam pembelajaran adalah bantuan terstruktur yang digunakan untuk membantu peserta didik menyelesaikan tugas baru dan memahami konsep yang tidak dapat dicapai jika dilakukan sendiri oleh peserta didik (Spectrum, 2008).

Scaffolding memiliki beberapa manfaat dan kelebihan. Scaffolding tidak hanya berpengaruh pada pengetahuan dan keterampilan peserta didik saja namun juga berpengaruh pada motivasi belajar. Hal ini sesuai dengan pernyataan Bikmaz, dkk (2010) bahwa peserta didik lebih termotivasi untuk belajar dan mereka merasa lebih baik ketika melaluinya. William dalam Bikmaz, dkk (2010) menyatakan bahwa scaffolding memberikan kesempatan pada peserta didik untuk mengembangkan kemandirian, kesadaran belajar dan percaya diri sambil mempelajari konsep matematika. Penerapan scaffolding dapat meningkatkan sikap dan performa peserta didik dalam pembelajaran matematika (Casem, 2013). Selain itu, scaffolding mampu menyediakan kesempatan bagi peserta didik untuk mendapatkan umpan balik (Skene dan Fedko, 2014). Kelebihan penerapan scaffolding adalah menantang peserta didik melalui penemuan dan pemahaman yang mendalam, melibatkan peserta didik pada diskusi kecil dan klasikal yang dinamis dan bermakna, memotivasi peserta didik untuk menjadi lebih baik (belajar bagaimana belajar), meningkatkan kemungkinan peserta didik mencapai tujuan pembelajaran, memberikan kesempatan untuk peer-teaching, menyediakan lingkungan belajar yang mendukung dan menyenangkan (Spectrum, 2008).

Scaffolding merupakan bantuan sementara yang diberikan oleh orang lain, yang dalam hal ini peneliti yang sekaligus bertindak sebagai dosen pengampu matakuliah Persamaan Diferensial. Jika mahasiswa sudah mampu menyelesaikan atau menguasai sendiri maka bantuan akan dihentikan. Scaffolding dipilih sebagai langkah perbaikan kesalahan mahasiswa dalam menyelesaikan persamaan diferensial karena dengan penerapan scaffolding peneliti lebih banyak berperan sebagai fasilitator daripada sebagai sumber utama belajar. Hal ini sesuai dengan pernyataan dalam Spectrum (2008) bahwa 
guru bukan lagi bertindak sebagai ahli atau sumber utama belajar namun akan menjadi fasilitator bagi peserta didik ketika scaffolding diterapkan dalam pembelajaran. Selain itu, dalam pembelajaran yang menerapkan scaffolding mahasiswa dapat bebas bertanya, mengajukan umpan balik dan membantu teman lain ketika mempelajari konsep baru. Mahasiswa akan lebih banyak terlibat dalam pembelajaran dan peran guru sedikit demi sedikit akan digantikan oleh mahasiswa sendiri.

Berdasarkan pemaparan di atas, tujuan penelitian adalah mendeskripsikan hasil analisis kesalahan dan scaffolding yang diterapkan dalam memperbaiki kesalahan matematika mahasiswa ketika menyelesaikan persamaan diferensial. Peneliti berharap agar hasil penelitian mampu memberikan gambaran bagaimana scafolding dapat diterapkan di kelas untuk membantu memperbaiki kesalahan dan menjadikan mahasiswa lebih mandiri dan terlibat aktif dalam pembelajaran. Penelitian ini juga diharapkan mampu menjadi referensi bagi peneliti lain yang ingin menganalisis kesalahan dan menerapkan scaffolding dalam pembelajaran atau penelitian lain yang terkait.

\section{Kesalahan}

Kesalahan merupakan bagian yang tidak dapat dipisahkan dalam pembelajaran matematika. Rach, dkk (2013) menyatakan bahwa kesalahan merupakan salah satu bagian penting dalam pembelajaran matematika. Hal ini sejalan dengan pendapat Ingram (2013) bahwa kesalahan dianggap penting dalam pembelajaran matematika, baik dari sisi guru maupun peserta didik. Dari perspektif guru, kesalahan dapat dijadikan dasar untuk mengetahui bagaimana peserta didik memahami konsep matematika. Dari perspektif peserta didik, membuat kesalahan merupakan dasar untuk mengkonstruksi sebuah konsep. Kesalahan juga dapat digunakan untuk mendukung pemahaman yang lebih mendalam terhadap matematika bagi peserta didik (Bray dan Santagata, 2013). Jadi, kesalahan bukanlah hal yang negatif dan selayaknya membutuhkan penanganan yang benar dalam pembelajaran matematika.

Analisis kesalahan digunakan untuk mengidentifikasi kesalahan dan penyebab kesalahan tersebut. Analisis kesalahan merupakan salah satu asesmen diagnosis yang dapat membantu guru dalam menentukan apa jenis kesalahan yang dilakukan peserta didik dan mengapa kesalahan tersebut dapat terjadi (Brown dan Skow, 2016). Ketterlin-Geller dan Yovanoff (2009) menyatakan bahwa analisis kesalahan merupakan salah satu metode yang dapat ditempuh untuk mengidentifikasi adanya kesalahpahaman peserta didik dalam 
mempelajari konsep matematika. Kesalahpahaman dalam suatu konsep bisa jadi berdampak pada pemahaman konsep lainnya karena konsep dalam matematika berhubungan antara satu dengan yang lain (Muzangwa dan Chifamba, 2012).

Analisis kesalahan memiliki tujuan dan manfaat dalam pembelajaran matematika. Tujuan analisis kesalahan adalah mereview pekerjaan peserta didik untuk mengidentifikasi jenis dan pola kesalahan secara spesifik dan membantu menentukan prioritas dalam pembelajaran (Riccomini, 2016). Manfaat adanya analisis kesalahan adalah membantu guru untuk (1) mengidentifikasi pada langkah mana peserta didik mampu menyelesaikan dengan benar tugas yang diberikan, (2) menentukan jenis kesalahan yang dilakukan peserta didik, (3) menentukan apakah kesalahan yang terjadi hanya sesaat atau kesalahpahaman mendasar pada suatu konsep atau prosedur, dan (4) memilih pendekatan pembelajaran yang efektif untuk mengatasi kesalahpahaman peserta didik dan mengajarkan konsep, strategi atau prosedur yang benar (Brown dan Skow, 2016).

Analisis kesalahan terdiri dari beberapa tahap. Riccomini (2016) menyatakan bahwa analisis kesalahan dapat dilakukan melalui empat tahap, yaitu (1) mengidentifikasi kesalahan dalam tugas yang diberikan, (2) mengelompokkan kesalahan (kesalahan konseptual, kesalahan prosedural, kesalahan faktual dan kecerobohan), (3) mengamati pola dari tiap jenis kesalahan, dan (4) menerapkan pembelajaran yang bertujuan untuk memperbaiki kesalahan. Penelitian ini hanya memperhatikan ketiga jenis kesalahan saja, yaitu kesalahan konseptual, kesalahan prosedural dan kesalahan faktual. Kesalahan akibat kecerobohan tidak diperhatikan dalam penelitian ini karena mahasiswa dapat segera memperbaiki kesalahannya dengan diingatkan saja.

Ketiga jenis kesalahan di atas memiliki beberapa karakteristik. Kesalahan konseptual terjadi ketika peserta didik mengalami kesalahpahaman dan kurang memahami konsep, prosedur, dan aplikasi yang bersesuaian (Riccomini, 2016). Sedangkan menurut Orton, kesalahan konseptual adalah kesalahan yang terjadi karena peserta didik tidak memahami konsep-konsep yang terlibat dalam masalah atau kesalahan yang timbul dari ketidakmampuan peserta didik untuk menentukan hubungan yang terlibat dalam masalah (Suwarno, 2016). Kesalahan prosedural diantaranya kesalahan yang berhubungan dengan kesamaan, perpangkatan, desimal, menyamakan pecahan, pengelompokan kembali (regrouping), dan penyelesaian persamaan yang sederhana (Riccomini, 2016). Sedangkan menurut Orton, kesalahan prosedural adalah kesalahan yang terjadi karena ketidakmampuan peserta didik untuk melakukan manipulasi atau algoritma meskipun 
memahami konsep yang terkait dengan masalah (Suwarno, 2016). Kesalahan faktual diantaranya kesalahan yang berhubungan dengan identifikasi tanda, digit, dan nilai tempat kesalahan perhitungan, dan penggunaan rumus yang tidak tepat (Riccomini, 2016).

Riccomini (2016) menawarkan beberapa hal yang perlu diperhatikan dalam penanganan tiap jenis kesalahan. Penanganan untuk kesalahan konseptual dapat dilakukan melalui pengulangan pembelajaran pada level yang lebih konkret dan/ atau representasional. Penanganan untuk kesalahan prosedural membutuhkan perbaikan yang spesifik dan disesuaikan dengan kesalahannya. Kesalahan prosedural paling banyak terjadi pada peserta didik dan akan terus terjadi pada jenjang selanjutnya jika tidak segera ditangani. Kesalahan prosedural terkadang sulit dibedakan dengan kesalahan prosedural. Penanganan untuk kesalahan faktual biasanya membutuhkan waktu yang lebih singkat.

\section{Scaffolding}

Scaffolding merupakan arahan yang diberikan pada peserta didik untuk melampaui apapun yang mereka ketahui pada apapun yang mereka akan pelajari (Amiripour, dkk, 2012). Scaffolding dalam pembelajaran adalah bantuan terstruktur yang digunakan untuk membantu peserta didik menyelesaikan tugas baru dan memahami suatu konsep yang tidak dapat dicapai jika dilakukan sendiri oleh peserta didik (Spectrum, 2008). Scaffolding adalah pendekatan untuk mencapai tujuan pembelajaran melalui serangkaian langkah yang dapat diatur dan didampingi dengan instruktur selama proses pembelajaran (Skene dan Fedko, 2014). Jadi, scaffolding merupakan bantuan sementara yang diberikan oleh orang lain untuk membantu peserta didik mencapai tujuan pembelajaran. Tujuan tersebut tidak akan dapat dicapai jika dilakukan sendiri oleh peserta didik.

Scaffolding membutuhkan peran dari orang lain yang lebih ahli, misalnya guru. Pada awalnya guru yang berperan dalam pembelajaran, namun sedikit-demi sedikit peserta didiklah yang akan mengambil peran tersebut. Guru bukan lagi bertindak sebagai ahli atau sumber utama belajar namun akan menjadi fasilitator bagi peserta didik ketika scaffolding diterapkan dalam pembelajaran (Spectrum, 2008). Peserta didik dapat bebas bertanya, mengajukan umpan balik dan membantu teman lain ketika mempelajari konsep baru. Penerapan scaffolding dapat tercapai dengan baik jika guru mampu membedakan apa yang dapat diselesaikan peserta didik secara mandiri dan apa yang dapat diselesaikan peserta didik dengan bantuan orang lain (Bikmaz, dkk, 2010). Dengan kata lain, guru harus mampu mengetahui ZPD (Zone of Proximal Development) dari peserta didik. Scaffolding 
mensyaratkan bahwa di kelas guru secara kontinu mendampingi peserta didik untuk mengakses ZPDnya (Amiripour, dkk, 2012).

Scaffolding dapat diterapkan melalui beberapa cara. Guru dapat menerapkan scaffolding yang tepat, misal melalui pernyataan, pertanyaan atau mekanisme serupa, untuk mengarahkan peserta didik agar mampu mengkonstruksi pengetahuan baru, memperbaiki kesalahan konsep atau yang belum tuntas, atau mengingatkan kembali pengetahuan yang terlupakan (Bikmaz, dkk, 2010). Selain itu, Roehler dan Cantlon dalam Bikmaz, dkk (2010) menyatakan bahwa terdapat lima jenis scaffolding yang biasanya digunakan yaitu (1) memberikan penjelasan, (2) menarik perhatian dan partisipasi peserta didik, (3) memverifikasi dan mengklarifikasi pemahaman peserta didik, (4) memodelkan tindakan yang diharapkan, dan (5) mengajak perserta didik untuk memberikan clue atau petunjuk.

Materi yang lebih kompleks akan membutuhkan sejumlah scaffolding yang diterapkan berulang kali untuk membantu peserta didik menguasai materi tersebut (Spectrum, 2008). Tabel 1 menyajikan beberapa scaffolding yang dapat diterapkan dalam pembelajaran menurut Alibali dalam Spectrum (2008).

Tabel 1 Penerapan Scaffolding dalam Pembelajaran

\begin{tabular}{ll}
\hline \multicolumn{1}{c}{ Jenis scaffolding } & \multicolumn{1}{c}{ Penerapan Scaffolding dalam Pembelajaran } \\
\hline Advance organizers & Alat-alat yang digunakan untuk mengenalkan materi dan tugas baru bagi peserta didik \\
\hline Kartu petunjuk (cue cards) & $\begin{array}{l}\text { Kartu yang disiapkan untuk membantu peserta didik berdiskusi tentang materi yang } \\
\text { dipelajari }\end{array}$ \\
\hline Peta konsep & Peta yang menunjukkan hubungan \\
\hline Contoh & Sampel, contoh, ilustrasi, masalah \\
\hline Penjelasan & $\begin{array}{l}\text { Informasi yang lebih rinci agar peserta didik dapat terus mengerjakan tugas atau } \\
\text { memahami konsep Petertentu }\end{array}$ \\
\hline Handout & $\begin{array}{l}\text { Handout yang memuat tugas dan materi namun dengan sedikit rincian dan tempat untuk } \\
\text { membuat catatan }\end{array}$ \\
\hline Petunjuk & Saran dan petunjuk \\
\hline Prompt & $\begin{array}{l}\text { Petunjuk secara fisik atau verbal untuk mengingatkan kembali peserta didik pada } \\
\text { pengetahuan awal atau lainnya }\end{array}$ \\
\hline Kartu pertanyaan (question & $\begin{array}{l}\text { Kartu yang memuat materi dengan pertanyaan spesifik yang diberikan pada individu atau } \\
\text { kelompok agar peserta didik dapat saling bertanya tentang materi yang dipelajari }\end{array}$ \\
\hline Cerita & $\begin{array}{l}\text { Cerita yang menghubungkan materi yang kompleks dan abstark dengan situasi yang } \\
\text { lebih dikenal oleh siswa }\end{array}$ \\
\hline Visual scaffolds & Menunjuk, gestur representasi, diagram, dan lain-lain \\
\hline
\end{tabular}

Beberapa hal perlu diperhatikan dalam penerapan scaffolding. Prinsip yang harus dipegang dalam penerapan scaffolding diantaranya adalah (1) menyesuaikan dukungan dengan tantangan yang diberikan pada peserta didik, (2) menerapkan bentuk scaffolding yang tepat, (3) menjadi pribadi yang menyenangkan dan terbuka bagi peserta didik (4) menciptakan lingkungan yang mendukung scaffolding, dan (5) merespon dan memberikan umpan balik terhadap pertanyaan dan komentar peserta didik sehingga mereka lebih bertanggungjawab terhadap apa yang mereka pelajari dan bagaimana mereka belajar 
(Bikmaz, dkk, 2010). Selain itu, perlu diperhatikan bahwa meskipun scaffolding lebih sering diterapkan secara individual antara guru dan satu perserta didik tertentu, namun scaffolding juga dapat diterapkan dengan baik secara klasikal di kelas (Spectrum, 2008).

Penerapan scaffolding juga memiliki beberapa tantangan. Tantangan tersebut diantaranya adalah membutuhkan waktu untuk merencanakan dan menerapkan scaffolding, memilih scaffolding yang tepat untuk kelas yang beragam, mengetahui kapan menghilangkan scaffolding sehingga peserta didik tidak menyadari adanya bantuan tersebut, terkadang tidak mengetahui dengan baik kemampuan kognitif dan afektif peserta didik untuk menerapkan scaffolding yang sesuai dengannya (Spectrum, 2008). Untuk menghadapi tantangan tersebut terdapat beberapa saran yang dapat digunakan. Saran untuk penerapan scaffolding yang mendukung pembelajaran matematika di kelas adalah (1) menggunakan umpan balik, (2) mengorganisasikan jawaban peserta didik, (3) menggunakan alat bantu, (4) menggunakan tutor sebaya, (5) menghilangkan kesalahpahaman, dan (6) menggunakan masalah nyata (Amiripour, dkk, 2012).

\section{METODE PENELITIAN}

Jenis penelitian merupakan penelitian kualitatif deskripstif yang bertujuan mendeskripsikan hasil analisis kesalahan dan scaffolding yang tepat dalam memperbaiki kesalahan matematika mahasiswa ketika menyelesaika persamaan diferensial. Penelitian dilaksanakan di IKIP Budi Utomo Malang. Subyek penelitian adalah mahasiswa program studi Pendidikan Matematika yang menempuh matakuliah Persamaan Diferensial. Data yang dikumpulkan dalam penelitian meliputi hasil pekerjaan mahasiswa terkait penyelesaian persamaan diferensial dan hasil wawancara dengan mahasiswa. Metode pengumpulan data dilakukan dengan memberikan tugas dan wawancara yang bersifat semi terstruktur. Instrumen penelitian adalah tugas dan pedoman wawancara. Soal dalam tugas yang diberikan kepada mahasiswa terkait penyelesaian persamaan diferensial variabel terpisah, reduksi variabel terpisah, homogen dan linier tidak homogen. Pedoman wawancara memuat pertanyaan pokok yang diajukan kepada mahasiswa untuk menggali lebih mendalam tentang kesalahan dan respon mahasiswa terhadap scaffolding yang diberikan selama pembelajaran.

Data yang sudah diperoleh kemudian dianalisis. Analisis data terdiri dari tahap reduksi data, penyajian data dan penarikan kesimpulan. Analisis data mengacu pada hasil analisis kesalahan dan penerapan scaffolding dalam pembelajaran. Tahap analisis 
kesalahan yaitu (1) mengidentifikasi kesalahan dalam tes yang diberikan, (2) mengelompokkan kesalahan menjadi kesalahan konseptual, prosedural dan faktual, sedangkan kesalahan karena kecerobohan diabaikan dalam penelitian, (3) mengamati pola dari tiap jenis kesalahan dan (4) menerapkan pembelajaran yang bertujuan untuk memperbaiki kesalahan. Kesimpulan dalam penelitian adalah deskripsi hasil analisis kesalahan dan scaffolding yang diterapkan dalam memperbaiki kesalahan matematika mahasiswa ketika menyelesaikan persamaan diferensial.

\section{HASIL DAN PEMBAHASAN}

Hasil analisis kesalahan menunjukkan bahwa ketiga jenis kesalahan yaitu kesalahan konseptual, prosedural dan faktual muncul ketika mahasiswa menyelesaikan persamaan diferensial. Kesalahan konseptual terkait dengan konsep dan prosedur dalam menurunkan, mengintegralkan dan menyelesaikan persamaan diferensial variabel terpisah, reduksi variabel terpisah, homogen dan linier tak homogen. Kesalahan prosedural terkait dengan ketidakmampuan peserta didik untuk melakukan manipulasi atau algoritma meskipun memahami konsep yang dalam menyelesaiakan persamaan diferensial. Kesalahan faktual terkait kesalahan perhitungan dalam menyelesaikan persamaan diferensial.

Kesalahan konseptual dalam menyelesaikan persamaan diferensial yaitu sebagai berikut: (1) Kesalahan dalam menentukan turunan dan integral terutama dari fungsi trigonometri, logaritma natural dan ekponensial. Kesalahan ini terjadi karena mahasiswa belum sepenuhnya memahami konsep turunan dan integral yang menjadi prasyarat matakuliah ini. (2) Kesalahan dalam menyimpulkan apakah persamaan diferensial membutuhkan faktor integral atau tidak. Kesalahan ini terjadi karena mahasiswa tidak sepenuhnya memahami kapan suatu persamaan diferensial membutuhkan faktor integral dalam penyelesaiannya dan mengapa ada faktor integral dalam penyelesaian persamaan diferensial. (3) Kesalahan dalam menyimpulkan apakah suatu persamaan diferensial yang diberikan homogen atau tidak. Kesalahan ini terjadi karena mahasiswa tidak sepenuhnya memahami definisi dari fungsi homogen dan persamaan diferensial homogen. (4) Kesalahan dalam menentukan faktor integral suatu persaman diferensial dengan reduksi variabel terpisah. Kesalahan ini terjadi karena mahasiswa hanya terpaku pada pola penentuan faktor integral pada soal-soal sebelumnya tanpa menyesuaikan persamaan diferensial yang diberikan. 
Kesalahan prosedural dalam menyelesaikan persamaan diferensial yaitu sebagai berikut: (1) Kesalahan dalam menyederhanakan persamaan diferensial yang mengandung pecahan rasional. Kesalahan terjadi karena mahasiswa tidak menerapkan prosedur penyederhanaan pecahan dengan benar, misal ketika memanipulasi pembilang pecahan, menyamakan penyebut pecahan dan menentukan dekomposisi pecahan. (2) Kesalahan dalam menyederhanakan hasil integral atau penyelesaian persamaan diferensial yang mengandung logaritma natural. Kesalahan ini terjadi karena mahasiswa tidak menerapkan sifat logaritma natural dengan benar, misalkan sifat logaritma natural $\ln a+\ln b=\ln (a b)$, $\ln a-\ln b=\ln \left(\frac{a}{b}\right)$ dan $n \ln a=\ln a^{n}$. (3) Kesalahan dalam mentransformasi persamaan diferensial homogen. Kesalahan terjadi karena mahasiswa tidak mensubstitusi variabel yang bersesuaian dengan benar.

Kesalahan faktual dalam menyelesaikan persamaan diferensial yaitu sebagai berikut: (1) Kesalahan dalam mengalikan semua ruas persamaan diferensial dengan suatu konstanta. (2) Kesalahan dalam mengoperasikan (menjumlahkan dan mengurangkan) suku-suku sejenis dalam persamaan diferensial. (3) Kesalahan dalam menentukan perbandingan koefisien-koefisien yang bersesuaian pada persamaan diferensial linier tak homogen. (4) Kesalahan dalam menghitung hasil $d x$ dan $d y$ pada kasus persamaan diferensial linier tak homogen. Kesalahan faktual tersebut di atas terjadi karena mahasiswa melakukan kesalahan perhitungan.

Secara umum kesalahan terjadi karena mahasiswa tidak mengoptimalkan pengetahuan awal yang sudah dimiliki terkait konsep turunan dan integral dan mahasiswa belum sepenuhnya memahami konsep dan prosedur dalam penyelesaian persamaan diferensial. Selain itu, mahasiswa juga sering menyelesaikan persamaan diferensial dengan hanya melihat dan meniru contoh yang sudah diberikan. Hal ini sesuai dengan hasil wawancara yang menyatakan bahwa mahasiswa banyak yang lupa, belum sepenuhnya memahami materi dan lebih banyak mengikuti contoh penyelesaian persamaan diferensial yang sudah ada dibandingkan memahami apa yang sebenarnya dikerjakan. Untuk menangani hal tersebut, scaffolding diterapkan selama memperbaiki kesalahan mahasiswa. Scaffolding diterapkan baik secara individu maupun klasikan di kelas.

Scaffolding diterapkan melalui variasi pemberian petunjuk, handout dan penjelasan pada mahasiswa. Handout memuat tugas dengan sedikit materi berupa contoh penyelesaian persamaan diferensial. Tugas yang diberikan disesuaikan dengan tujuan pembelajaran dan 
kondisi mahasiswa. Materi diberikan dalam handout agar mahasiswa bisa lebih mandiri selama menyelesaikannya. Petunjuk dan penjelasan diberikan untuk mengarahkan perhatian dan pemikiran mahasiswa pada apa yang seharusnya dilakukan. Perbaikan kesalahan juga diterapkan dengan memberikan umpan balik dan motivasi terhadap mahasiswa. Umpan balik yang diberikan terkait dengan pertanyaan dan komentar mahasiswa dalam menyelesaikan persamaan diferensial. Motivasi diberikan agar mahasiswa tidak cepat bosan dan menyerah dalam menyelesaikan persamaan diferensial.

Variasi penerapan scaffolding ditujukan untuk mengoptimalkan kemampuan mahasiswa dalam menyelesaikan persamaan diferensial. Dengan kata lain, selain mampu memperbaiki kesalahannya mahasiswa juga memperoleh pemahaman yang lebih mendalam terkait penyelesaian persamaan diferensial. Pemberian handout melatih mahasiswa untuk aktif memahami prosedur (bagaimana) penyelesaian persamaan diferensial secara mandiri, sedangkan melalui petunjuk dan penjelasan melatih mahasiswa untuk memahami konsep (apa dan mengapa) terkait penyelesaian persamaan diferensial. Hal ini sesuai dengan pernyataan dalam Spectrum (2008) bahwa penerapan scaffolding mampu meningkatkan pemahaman peserta didik, yang dalam hal ini adalah mahasiswa. Peningkatan pemahaman mahasiswa ini mengarahkan pada tercapainya tujuan pembelajaran. Pemberian umpan balik dan motivasi selama penerapan scaffolding mampu menciptakan lingkungan yang mendukung pembelajaran. Mahasiswa tidak perlu takut lagi ketika melakukan kesalahan dalam menyelesaikan persamaan diferensial. Mahasiswa juga lebih mandiri dan terlibat aktif dalam pembelajaran. Hal ini menunjukkan sikap dan performa yang baik selama pembelajaran sesuai dengan pernyataan dari Casem (2013) bahwa penerapan scaffolding dapat meningkatkan sikap dan performa peserta didik dalam pembelajaran matematika.

\section{KESIMPULAN}

Berdasarkan hasil analisis data dapat disimpulkan sebagai berikut.

1. Kesalahan yang muncul dalam menyelesaikan persamaan diferensial adalah kesalahan konseptual, prosedural dan faktual. Penyebab kesalahan secara umum karena mahasiswa tidak mengoptimalkan pengetahuan awal yang sudah dimiliki terkait konsep turunan dan integral dan mahasiswa belum sepenuhnya memahami konsep dan prosedur dalam penyelsaian persamaan diferensial. Selain itu, mahasiswa juga sering 
menyelesaikan persamaan diferensial dengan hanya melihat dan meniru contoh yang sudah diberikan.

2. Kesalahan konseptual terdiri dari kesalahan dalam menentukan turunan dan integral terutama dari fungsi trigonometri, logaritma natural dan ekponensial, kesalahan dalam menyimpulkan apakah persamaan diferensial membutuhkan faktor integral atau tidak, kesalahan dalam menyimpulkan apakah suatu persamaan diferensial yang diberikan homogen atau tidak dan kesalahan dalam menentukan faktor integral suatu persaman diferensial dengan reduksi variabel terpisah.

3. Kesalahan prosedural terdiri dari kesalahan dalam menyederhanakan persamaan diferensial yang mengandung pecahan rasional dan kesalahan dalam menyederhanakan hasil integral atau penyelesaian persamaan diferensial yang mengandung logaritma natural.

4. Kesalahan faktual terdiri dari kesalahan dalam mengalikan semua ruas persamaan diferensial dengan suatu konstanta, kesalahan dalam mengoperasikan (menjumlahkan dan mengurangkan) suku-suku sejenis dalam persamaan diferensial, kesalahan dalam menentukan perbandingan koefisien-koefisien yang bersesuaian pada persamaan diferensial linier tak homogen dan kesalahan dalam menghitung hasil $d x$ dan $d y$ pada kasus persamaan diferensial linier tak homogen.

5. Perbaikan kesalahan dilakukan melalui penerapan scaffolding yang merupakan variasi dari pemberian petunjuk, handout dan penjelasan pada mahasiswa baik secara individual dan klasikal di kelas. Variasi penerapan scaffolding juga didampingi dengan pemberian umpan balik dan motivasi terhadap mahasiswa. Variasi penerapan scaffolding ditujukan untuk mengoptimalkan kemampuan mahasiswa dalam menyelesaikan persamaan diferensial. Mahasiswa juga lebih mandiri dan terlibat aktif dalam pembelajaran. Jadi, selain mampu memperbaiki kesalahannya mahasiswa juga memperoleh pemahaman yang lebih mendalam terkait penyelesaian persamaan diferensial sekaligus meningkatkan sikap dan performanya dalam pembelajaran.

\section{REKOMENDASI}

Rekomendasi dari peneliti adalah sebagai berikut.

1. Analisis kesalahan sebaiknya dilakukan secara berkelanjutan dalam pembelajaran karena analisis kesalahan mempunyai banyak kelebihan seperti dipaparkan dalam penjelasan di atas. 
2. Penerapan scaffolding sebaiknya diberikan secara bervariasi dan disesuaikan kondisi mahasiswa atau peserta didik baik secara individual maupun klasikal agar tujuan pembelajaran dapat tercapai dengan baik.

3. Penelitian selanjutnya dapat menerapkan scaffolding dalam setting penelitian tindakan kelas (PTK) atau penelitian eksperimen dan untuk materi yang lainnya.

\section{REFERENSI}

Amiripour, P., Amir-Mofidi, S., \& Shahvarani, A. (2012). Scaffolding as effective method for mathematical learning. Indian Journal of Science and Technology, 5(9), 33283331 .

Bikmaz, F. H., Celebi, O., Ata, A., Ozer, E., Soyak, O., \& Recber, H. (2010). Scaffolding Strategies Applied by Student Teachers to Teach Mathematics. The International Journal of Research in Teacher Education, 1(Special Issue), 25-36. Diperoleh dari http://ijrte.eab.org.tr/1/spc.issue/3f.hazir.pdf

Bray, W. \& Santagata, R. (2013). Proceedings on Annual Metting Association of Mathematics Teacher Educators: Developing teaching capacity for making productive use of mathematical errors. Orlando Florida.

Brown, J., Skow, K., \& the IRIS Center. (2016). Mathematics: Identifying and addresing studen errors.

Casem, R. Q. (2013). Scaffolding strategy in teaching mathematics: Its effects on students' performance and attitudes. Journal of Educational Research, 1(1), 9-19.

Ingram, J., Baldry, F. \& Pitt, A. (2013). Proceedings on Eight Congress of the European Society for Research in Mathematic Education: The influence of how teachers interactionaliiy manage mathematical mistakes on the mathematics that student experience. Antalya, Turki.

Ketterlin-Geller, L. R., \& Yovanoff, P. (2009). Diagnostic assessments in mathematics to support instructional decision making. Practical Assessment, Research \& Evaluation, 14(16). Retrieved from http://pareonline.net/getvn.asp?v=14\&n=16.

Legutko, M. (2008). Handbook of mathematics teaching research: Teaching experiment- $a$ tool for teacher-reseacher. University of Rzeszow.

Muzangwa, J. \& Chifamba, P. (2012). Analysis of errors and misconceptions in the learning of calculus by undergraduate students. Acta Didactica Napocensia, 5(2). Retrieved from http://dppd.ubbcluj.ro/adn/article_5_2_1.pdf

Pazzani, M. J. (1991). Influence of prior knowledge on concept acquisition: experimental and computational results. Journal of Experimental Psychology, 17(3), 416-432.

Rach, S., Ufer, S., \& Heinze, A. (2013). Learning from errors: effect of teachers training on students' attitudes towards and their individual use of errors. PNA, 8(1), 21-30.

Riccomini, P. J. (2016). How to use math error analysis to improve instruction (PowerPoint Slides). Retrieved from http://files.ernweb.com/erroranalysis.pdf

Schnepper, L. C. \& McCoy, L. P. (2013). Analysis of Misconceptions in High School Mathematics, Network, 15(1). Diperoleh dari http://journals.library.wisc.edu/index.php/networks/article/download/625/627

Skene, A. \& Fedko, S. (2014). Instructional scaffolding. Scarborough: Center for Teching and Learning University Toronto.

Spectrum. (2008). Instructional scaffolding to improve learning. Diperoleh dari http://niu.edu/spectrum/archives/scaffolding.shtml 
Suwarno. (2016). Penerapan Model Tutorial Berbantuan Mathematica untuk Meningkatkan Pemecahan Masalah Matematis. KALAMATIKA, 1(1), 47-57.

White, A. J. (2005). Active mathematics in classroom: Finding out why children make mistakes and then doing something to help them. Square One, 15(5), 15-19.. 